(7)

\title{
Involvement of Social and Cognitive Factors in Reading Skills of Boys and Girls: A Comparative Study
}

\author{
${ }^{a}$ Ammara Farukh, ${ }^{\text {b }}$ Masroor Sibtain, ${ }^{c}$ Hafiz Muhammad Qasim, ${ }^{\text {d }}$ Asma Kashif Shahzad \\ ${ }^{a}$ Assistant Professor, Department of English, University of Education, Lahore, Vehari Campus \\ Email:ammara.farukh@ue.edu.pk \\ b Assistant Professor of English, Govt. College of Science, Multan, Email: masroorsibtain@gmail.com \\ ${ }^{c}$ Assistant Professor, Department of Applied Linguistics, GC University, Faisalabad \\ Email: muhammadqasim@gcuf.edu.pk) \\ ${ }^{\mathrm{d}}$ Assistant Professor, COMSATS University Islamabad, Vehari Campus, Email: asmashahzad@cuivehari.edu.pk
}

\begin{tabular}{l}
\hline ARTICLE DETAILS \\
\hline History: \\
Accepted 29 March 2020 \\
Available Online 31 March 2020
\end{tabular}

Keywords:

Gender Differences; Literacy

Skills; L1 Reading; L2 Reading;

Word Reading

JEL Classification:

J16, $P_{3} 6, P_{4} 6$

DOI: $10.47067 /$ reads.v6i1.192

\begin{abstract}
It has been a controversial issue to ascertain whether girls have an advantage in literacy skills over boys or not. There are studies showing a minor or no lead of girls in literacy skills (White, 2007). On the other hand, several studies described better literacy skills in girls than boys (Ready, LoGerfo, Burkam\& Lee, 2005; Coley, 2001). Reasons like differences in biology,cognitive and physical maturation (Leinhardt, Seewald \& Engel, 1979) are given to explain these differences. In this study, 8-9 years 66 grade 3 children were tested on loud reading tasks in both Urdu and English.The children were extracted from a bigger sample which participated in a previous study. In the present study, we used 3-word lists (words of mixed difficulty, pseudo-words, and easy frequent words) in both Urdu and English (3+3). A t-test was run to see the difference of performance on all word reading tasks by girls, and boys. The girls scored higher than boys on all Urdu and English tasks, except pseudo-words in Urdu where the difference was not significant whereas a tendency towards significance could be seen. The results presented evidence in favour of the advantage (cognitive or social) of girls over boys of the same age and grade.
\end{abstract}

(C) 2020 The authors. Published by SPCRD Global Publishing. This is an open access article under the Creative Commons Attribution-

NonCommercial 4.0

\section{Introduction}

It has been a controversial issue to determine the role of differences in gender in the literacy skills of older and young children. For, a large number of children observed no gender differences in the early grades (Entwisle, Alexander \& Olson, 1997; Davies \& Brember, 1999). These observations were also confirmed even for secondary level (Waber, 1979). In these studies, girls showed either no lead or a minor advantage in literacy skills (e.g. Below, Skinner, Fearrington, \& Sorrell, 2010). On the other hand, several studies e.g. Coley (2001), Gambell and Hunter (1999), Phillips, Norris, Osmond and 
Maynard (2002), Ready, LoGerfo, Burkam and Lee, (2005) described better literacy skills in girls than boys. To investigate the idea that girls come to schools with better literacy skills than boys, Below, Skinner, Fearringtonand Sorrell (2010) used repeated measures analyses of multiple preliteracy skills across 5 grades $(1-5)$. They observed that the girls score higher than the boys on four pre-literacy skills, but the differences were not significant. They did not find any significant gender difference on the selected literacy tasks until in the fourth-grade sample where the female students were observed to benefit significantly. Again, in the 5th-grade sample, these differences were insignificant. In grade 5 sample boys presented greater upturns in oral reading fluency, and when the academic year ended, oral reading fluency scores of both boys and girls were almost similar.

Similarly, seven graders (Gates, 1961) were investigatedand it was observed that the female students were better on 18 from 21 comparisons of reading measures. Great differences were reported in comprehension, speed and vocabulary skills. In another study (Chatterji, 2006), it was also observed that male-students scored below than that of the female ones on different tests i.e. beginning and ending sounds, letter recognition, listening comprehension, print familiarity, receptive vocabulary, rhyming sounds, word recognition, and word comprehension in the context. The difference was observed to increase as the literacy training of a year was over until the end of grade 1. Explanations like differences in biology, cognitive and physical development (Leinhardt, Seewald, \&Engel, 1979) have been presented to support the observed better performance of girls on literacy tasks. The difference of learning approaches (Ready, LoGerfo, Burkam, \& Lee, 2005) to the dissimilar cultural expectations reserved for males and females are also considered as important factors for the observed difference (Sommers, 2001).

Ayers (1909) also showed concern over a deficit in males in reading success. The results were confirmed later by different researchers with different populations, and measures, across different age/grade ranges. It was also emphasized that physiological developmental and cultural or societal aspects might affect the deficits of male students in reading skills (see Alloway \& Gilbert, 19970; Holbrook, 1988). Researchers of physiological-maturational theories like Das, Kirby and Jarman(1979), Geschwind and Behan (1982), Mills (2003), Naour (2001), Waber (1979) and Witelson (1976) investigated the processing variances. Sequential-processing was referred to as the ability to process information in the sequence. Similarly, synchronized-processing was described as the ability to unite different parts of the information to form meaningful products. Studies by Geschwind and Behan (1982), and Waber (1979) reported the presence of bigger levels delay in the fetal-testosterone maturation process of the left-brain hemisphere, causing the boys to lag behind in the activities which involve left hemisphere like sequential processing.Therefore, the male students are most likely to perform better on synchronized-processing tasks (i.e. visual) and inferior on sequential-processing tasks (i.e. auditory) (Mills, 2003; Witelson, 1976).

Although both of these types of processing (i.e. auditory and visual), in the view of Das, Kirby and Jarman (1979), Naour (2001) and Witelson (1976) are related to development of reading skill yet, the problems related with the sequential-processing may directly be related to early literacy skill development. Another factor discussed is environmental factors. It has been suggested that the gender differences affecting the reading skills are caused due to the cultural, environmental,or societal factors. In this context, a theory has also been presented i.e. differential response theory. It embarked on the notion that the behaviour of a teacher toward his/her students is subjective to the students' behaviour and his/her (teacher's) perception about what those learners areexpected to do. Itentails, as perceived by Bank, Biddle and Good (1980) that the teacher may hold greater expectations for the female students that turn into self-fulfilling predictions. A study (Maccoby, 1990) found evidence for this assumption by 
recording theteacher's interactions with the students of grade-2 in mathematics and reading lessons. It was observed that the teachers spent moreinstructional-time as well as interact more with the female students in reading lessons. On the other hand, the teachers spent more instructional-time and interacted more with male students in math lessons. Although the differences in achievement were small initially in reading and math, yet the differences favouring females in reading achievement scores were evident in the end of the year.

Large-scale reading assessments, constantly observed that girls, overall, exceed boys in reading abilities e.g. studies from 8 to 16 years boys and girls sustained reporting this gender difference at both national and international levels (CMEC, 1999; Elley, 1992;EQAO, 2003; NAEP, 2005; Naour, 2001). Yet, contrary to all such findings, a study by Witelson(1976), suggested that there are no practical consequences of this difference and that the idea of boys' under-achievement has been exaggerated. The data for this study were taken from the reading component of Ontario Secondary School Literacy Test (i.e. $\mathrm{N}=113050$ ). The gender effects could explain no effect of gender in reading achievement. In this study, 8-9 years grade 3 children, with varied reading abilities (both typical, and poor readers) were tested on loud reading tasks in both Urdu and English.We used 3-word lists (words of mixed difficulty, pseudo-words, and easy frequent words) in both Urdu and English. Each list consisted of 10 items. The objective of this research was to explore if there lay any effect of gender on the performance of the participants on the said reading tasks.

\section{Participants and Procedure of the Study}

For this study, 66 school children chosen as the participants from a sample of 150 grade-3 children ( 54 girls and 96 boys) from a previous study by Farukh \& Vulchanova(2014) . The participants were studying at both public and private sector schools of a developing district in the Punjab, Pakistan. They were previously evaluated for reading skills on a classical RAN battery and a non-word repetition task (Denckla \& Rudel, 1976) after the addition of a RAN task designed in Urdu (Farukh \&Vulchanova, 2014). Scores for the rapid automatised naming of colours, letters, objects, numbers, and reading speed, and errors in the repetition process of four-syllable non-words, facilitated the further distribution of the students into different groups i.e. a) Control group and b) Reading Deficit (RD) group. The former comprised of the students scoring between the $25^{\text {th }}$ and $75^{\text {th }}$ percentile whereas, the later comprised of

the students scoring below the 25th percentile on three or more tasks. Hence, avoiding the inclusion of the top performers, the study considered the control group children from Urdu public and English Private schools $(\mathrm{N}=32)$, and children with a reading deficit, RD Group from the same schools $(\mathrm{N}=34)$.

\subsection{Testing procedure}

To ensure that the groups did not differ on non-verbal intelligence, and to rule out the possibility of any cognitive deficit, prior to the actual testing, the participants were tested on the selected standard non-verbal IQ tasks adapted and performed in Urdu.

\subsection{Word Reading Tasks and Scoring}

Thechildrenweretestedonabatteryoftasks designed for the study, including three lists of words (in English and in Urdu). The1stlist included words of mixed difficulty, the 2nd list included pseudowords, and the 3rd list included easy frequent words. Each list included 10 words to read aloud. 1 point was given for each correct response meaning that for each list of 10 words the maximum score was 10.

\section{Results}

A t-test was run to see the difference of performance on all word reading tasks by girls, and boys. The girls scored higher than boys on all Urdu and English tasks. The results were as follows: for 
mixed words English, ; t-value $=2.48, \mathrm{df}=64, \mathrm{p}<$.001; for pseudo-words English; t-value $=2.66$, $\mathrm{df}=$ $64, \mathrm{p}<.001$; and for easy frequent words English, ; t-value $=3.12$, $\mathrm{df}=64, \mathrm{p}<.001$. The betweensubject effects for reading lists in Urdu were as follows: for mixed words Urdu, ; $t$-value $=2.71, \mathrm{df}=64$, $\mathrm{p}=.002$; for pseudo-words Urdu, ; t-value $=1.75, \mathrm{df}=64, \mathrm{p}=.02$; and for easy frequent words Urdu, ; $\mathrm{t}$-value $=2.35$, df $=64, \mathrm{p}<.001$. A descriptive statistics table is given in appendix A. to explain the scores. Bonferroni correction method, for 6 independent comparisons, was applied and, the significance level was set as .oo8. There seems to exist a significant difference in the word reading scores of the male and female participants on all word lists (both in English and Urdu) except on pseudo-words in Urdu where the difference is not significant, whereas we can observe a trend towards significance.

\section{Discussion}

The results of the study show a significant difference in loud word reading scores in both English and Urdu. These results(see also Appendix. 1) support the claim of the studies,performed on an international scale,by Coley (2001), Gambell and Hunter (1999), Phillips et al., (2002) and Ready et al. (2005) that girls are better in literacy skills than boys.They enjoy an advantage over the boys in being literate. Biological differences in cognitive development and physical maturationare considered responsible for such differences(Leinhardt et al.,1979). The girls are also thought to adopt different learning approaches (Ready et al.,2005) to meet with the dissimilar cultural expectations reserved for males and females (Sommers, 2001). Although there is a small number of studies that do not conform to such results (Entwisle, Alexander \& Olson, 1997; Davies \& Brember, 1999; White, 2007), such studies report a minor or no difference between the literacy outcomes of boys versus girls.

If we have a look at the studies that presented a significant difference in literacy perception and academic achievements, we find literature assigning the feminized educational practices as well as structures being responsible for it (Sommers, 2001). Some of the strategies have also been suggested for classroom use to mediate this gender gap i.e. a) the use of materialswhich are more boy-friendly, b) introduction to more male teachers and male role-models, c) adoption of technology-based educational programmes, and d) experimentation with single-gender schooling (Alloway \& Gilbert, 1997; Gurian, Henley \& Trueman, 2001; Mills, 2003; Noble \& Bradford, 2000). All of this literature suggests changed teaching and professional practices. Most of the educational systems on the international level are supposed to suit more to girls than boys (Mills, 2003). Therefore, some practical steps might be takento adapt the curricula taking biological, cognitive, psychological, and social differences between boys and girls.

The present study presented girls advantage in loud word reading over boys but, the reason for this difference still needs to be investigated to reach the factors thateither this is the curriculum or social and cognitive factors which are responsible for the difference in this particular age group. The sample of the present study is too small to be decisive about the suitability of curriculum of the Pakistani education system. There might be a study conducted on a large scale to support the idea if the difference observed really exists or not. There is also another limitation of the study that it did not control the participants for their cognitive abilities. Any future study should take the cognitive ability measures into account. The study could include other literacy skills like text reading, writing, etc. in both Urdu and English.

\section{References}

Alloway, N., \& Gilbert, P. (1997). Boys and literacy: Lessons from Australia. Gender and Education, 9(1), 49-6o.

Ayers, L. (1909). Laggards in our schools. New York: Russell Sage Foundation. 
Bank, B. J., Biddle, B. J., \& Good, T. L. (1980). Sex roles, classroom instruction, and reading achievement. Journal of Educational Psychology, 72, 119-132.

Below, J. L., Skinner, C. H., Fearrington, J. Y., \& Sorrell, C. A. (2010). Gender differences in early literacy: Analysis of kindergarten through fifth-grade dynamic indicators of basic early literacy skills probes. School Psychology Review, 39(2), 240.

Chatterji, M. (2006). Reading achievement gaps, correlates, and moderators of early reading achievement: Evidence from the Early Childhood Longitudinal Study (ECLS) kindergarten to first-grade sample. Journal of Educational Psychology, 98, 489-507.

Coley, R. J. (2001). Differences in the gender gap: Comparisons across racial/ethnic groups in education and work. Princeton, NJ: Educational Testing Service.

Council of Ministers of Education, Canada [CMEC]. (1999).

Das, J. P., Kirby, J. R., \& Jarman, R. F. (1979). Simultaneous and successive cognitive processes. New York: Academic Press.

Davies, J., \&Brember, I. (1999). Boys outperforming girls: An 8-year cross-sectional study of attainment and self-esteem in year 6. Educational Psychology,19 (1), 5-13.

Denckla,M.B.,\&Rudel,R.G.(1976).Rapidautomatizednaming(R.A.N.):Dyslexiadifferentiatedfromotherlear ningdisabilities.Neuropsychologia,vol.14,471-479.

Education and Quality and Accountability Office [EQAO]. (2003). Ontario English language schools. Retrieved July 16, 2007, from http://www.eqao.com/pdf_e/03/o3Poo6e.pdf

Elley, W. (1992). How in the world do students read? The Hague: International

Association for the Evaluation of Educational Achievement.

Entwisle, D. R., Alexander, K. L., \& Olson, L. S. (1997). Children, schools, and inequality. Boulder, CO: Westview.

Farukh,A.,\&Vulchanova,M.(2014).PredictorsofReadinginUrdu:DoesDeepOrthographyHaveanImpact?.Dy slexia,20(2),146-166.

Gambell, T. J., \& Hunter, D. M. (1999). Rethinking gender differences in literacy. Canadian Journal of Education,24 (1), 1-16.

Gates, A. I. (1961). Sex differences in reading ability. The Elementary School Journal, 61, 431-444.

Geschwind, N., \& Behan, P. (1982). Left-handedness: Association with immune disease, migraine, and developmental learning disorder. Proceedings of the National Academy of Science, 79, 50975100.

Gurian, M., Henley, P., \&Trueman, T. (2001). Boys and girls learn differently. Hoboken.

Holbrook, H. T. (1988). Sex differences in reading: Nature or nurture? Journal of Reading, 31, 574-577.

Maccoby, E. E. (1990). Gender and relationships: A developmental account. American Psychologist,45 (4), 513-520.

Leinhardt, G., Seewald, A., \& Engel, M. (1979). Learning what's taught: Sex differences in instruction. Journal of Educational Psychology, 71, 432-439.

Mills, M. (2003). Shaping the boys' agenda: The backlash blockbusters. International Journal of Inclusive Education, 7(1), 57-73.

Naglieri, J. A., \& Rojahn, J. (2001). Gender differences in planning, attention, simultaneous, and successive (PASS) cognitive processes and achievement. Journal of Educational Psychology, 93, 430-437.

Naour, P. J. (2001). Brain/behaviour relationships, gender differences, and the learning disabled. Theory Into Practice, 24, 100-104.

National Assessment of Educational Progress [NAEP]. (2005). NAEP 2004 Trends in Academic Progress: Three decades of student performance in reading and mathematics.

Noble, C., \& Bradford, W. (2000). Getting it right for boys--and girls. Psychology Press.

Organisation for Economic Co-Operation and Development [OECD] PISA (2001).Knowledge and skills. 
First results from PISA, Paris: OECD Publications.

Phillips, L. M., Norris, S. P., Osmond, W. C., \& Maynard, A. M. (2002). Relative reading achievement: A longitudinal study of 187 children from first through sixth grades. Journal of Educational Psychology,94 (1), 3-13.

Ready, D. D., LoGerfo, L. F., Burkam, D. T., \& Lee, V. E. (2005). Explaining girls' advantage in kindergarten literacy learning: Do classroom behaviours make a difference?. The Elementary School Journal, 106(1), 21-38.

Sommers, C. H. (2001). The war against boys: How misguided feminism is harming our young men. New York: Simon \& Schuster.

Waber, D. P. (1979). Cognitive abilities and sex-related variations in the maturation of cerebral cortical functions. In M. A. Wittig \& A. C. Peterson (Eds.), Sex-related differences in cognitive functioning (pp. 161- 186). New York: Academic Press.

White, B. (2007). Are girls better readers than boys? Which boys? Which girls?.Canadian Journal of Education/Revue Canadienne de l'éducation, 554-581.

Witelson, S. F. (1976). Sex and the single hemisphere: Specialization of the right hemisphere for spatial processing. Science, 193, 425-427.

\section{Appendix}

\section{Appendix 1.Group Statistics}

\begin{tabular}{|l|l|l|l|l|l|}
\hline & Gender & $\mathrm{N}$ & Mean & Std. Deviation & Std. ErrorMean \\
\hline \multirow{2}{*}{ MixedwordsEng } & girls & 22 & 6.18 & 1.71 & .364 \\
\cline { 2 - 6 } & boys & 44 & 4.41 & 3.12 & .470 \\
\hline \multirow{2}{*}{ Pseudo-wordsEng } & girls & 22 & 7.23 & 1.57 & .335 \\
\cline { 2 - 6 } & boys & 44 & 5.20 & 3.38 & .510 \\
\hline \multirow{2}{*}{ EasyFrequentEng } & girls & 22 & 9.32 & .95 & .202 \\
\hline \multirow{2}{*}{ Mixedwordsurdu } & boys & 44 & 6.93 & 3.51 & .530 \\
\hline \multirow{2}{*}{ Pseudo-wordsUrdu } & girls & 22 & 8.55 & 2.20 & .469 \\
\hline \multirow{2}{*}{ EasywordsUrdu } & boys & 44 & 6.27 & 3.60 & .542 \\
\hline & girls & 22 & 7.32 & 2.38 & .507 \\
\hline & boys & 44 & 5.89 & 3.43 & .517 \\
\hline & girls & 22 & 8.95 & 1.84 & .392 \\
\hline
\end{tabular}

